\title{
THE LINK BETWEEN THE BRENT CRUDE OIL PRICE AND THE US DOLLAR EXCHANGE RATE
}

\author{
Filip Novotný*
}

\begin{abstract}
:
Growth in the intensity of the inverse relationship between the US dollar exchange rate and the Brent crude oil price has been observed over the last decade. This may be linked, among other things, to the growing role of commodities as an alternative investment instrument at times of excess liquidity and low interest rates on global markets. This analysis examines monthly data from January 1982 to September 2010. Since 2002 the direction of the relationship in the Granger causality sense has been from the dollar exchange rate to the oil price. A weakening of the dollar of $1 \%$ causes the Brent oil price to rise by $2.1 \%$. The contrary movements in the Brent oil price and the dollar exchange rate are a factor dampening the impact of sharp fluctuations in the dollar price of oil on "non-dollar" economies, including the Czech Republic. This dampening effect was clearly visible in the period of sharp oil price growth in 2007 and 2008.
\end{abstract}

Keywords: commodity prices; excess liquidity; exchange rate movements; financial markets; interest rates; speculative demand

JEL Classification: F31; G15

\section{Introduction}

The link between the oil price and the US dollar exchange rate, which can be observed since the 1990s, is attracting the interest of many economists. The fact that commodity prices are mostly denominated in US dollars ${ }^{1}$ naturally leads to a question regarding the relationship between commodity prices and the dollar exchange rate. There are essentially two approaches examining the links between the oil price and exchange rates in the literature. The first approach examines the real effective exchange rates of specific currencies and uses the real price of oil as a proxy for changes in the terms of trade (Amano and van Norden, 1998a,b; Chaudhuri and Daniel, 1998; BénassyQuéré et al., 2005; Habib and Kalamova, 2007). This approach usually finds a strong

* Filip.Novotny@cnb.cz, Czech National Bank, External Economic Relations Division, Na Př́kopě 28, Prague 1, 11503, Czech Republic. The topic was initiated during the author's secondment at the European Central Bank, EU Neighbouring Regions Division in 2009. Furthermore, the author has benefited from valuable comments from the External Economic Relations Division of the Czech National Bank and from the three anonymous referees of the PEP journal. The views expressed in this paper are those of the author and do not necessarily represent those of the Czech National Bank.

1 Commodities are traded in a single currency for reasons of transparency, cost and risk (Mileva and Siegfried, 2007). 
interdependence of the two variables, with the real price of oil affecting the real effective exchange rates of the countries under review. Given the high share of oil in the total imports of most industrial countries, this conclusion is in line with economic intuition.

This analysis, however, uses the second approach, which examines the relationship between the price of oil and the exchange rate of the currency in which oil is traded, i.e. the US dollar. According to Muñoz and Dickey (2009), fluctuations of the US dollar affect oil prices simply because commodity prices are quoted in US dollars. The results of this approach essentially confirm contrary movements of the two variables, i.e. a weakening dollar causes prices of oil and other commodities to rise and a strengthening dollar conversely causes them to fall (Cuaresma and Breitenfellner, 2008; Brown et al., 2008; European Commission, 2008; Schulmeister, 2009; Lizardo and Mollick, 2010; Hošek et al., 2011).

There are several explanations for the inverse relationship between the oil price and the US dollar exchange rate. One of them involves the growing role of investors in commodity markets related to falling financial asset returns in advanced countries. In this case, oil is a recognised investment asset used as a means of diversifying the risk of inflation, the risk of US dollar depreciation or the risk of a stock market decline. Furthermore, a depreciation of the US dollar or an easing of monetary policy in the USA implies an easing of the monetary conditions in countries whose exchange rate is tied to the dollar. Oil-exporting countries and China are typical examples.

Demand in these countries, including demand for oil products, then increases, reinforcing the effect of US monetary policy on commodity market prices. In addition, a weakening of the dollar against the currencies of countries with floating exchange rates means that the oil price in local currency becomes lower. This can cause a rise in demand for oil in these countries as well (for details, see, for example, Cuaresma and Breitenfellner, 2008, p. 7).

The rest of the paper is organized as follows: In Part 2, the intensity and direction of the relationship between the nominal effective exchange rate of the US dollar and the price of Brent crude oil and other commodities (gold, industrial metals and agricultural commodities) are analyzed in the period of 1982-2010. Examination of nominal variables is according to Zhang et al. (2008) relevant in order to capture financial attribute of international crude oil markets, and the growing interaction between oil markets and financial markets. In Part 3, a regression equation of the Brent oil price is then estimated, with one of the explanatory variables being the nominal effective exchange rate of the US dollar. The implications of the inverse relationship between the value of the dollar and the price of oil for "non-dollar" net importers of oil, including the Czech Republic, are analysed as well. The final Part 4 then summarises the main findings. 


\section{Analysis of the Intensity and Direction of the Relationship}

In this part, we observe the relationship between the nominal effective exchange rate of the US dollar and selected commodities with the main focus on the crude oil. Due to data availability, we start in 1982 onward. However, the price of oil was quite stable until the 2000 s and it oscillated between $\$ 10$ and $\$ 36$ a barrel. The intensity of the relationship between the Brent crude oil price and the US dollar exchange rate has been elevated since 2002 (see Figure 1), with the gradually rising price of Brent oil being accompanied by depreciation of the US dollar. The year 2002 is therefore supposed to be the principal turning point. From the year of 2000 to 2002, oil price was evidently slashed while the US dollar exchange rate continuously appreciated. Whereas, since the year of 2002 the picture has changed totally. Specifically, oil price has risen sharply while the US dollar has increasingly depreciated. This trend peaked in 2008, when the effective dollar exchange rate ${ }^{2}$ weakened to a historical low in March and the average monthly price of Brent oil then reached an all-time high of $\$ 134$ a barrel in July.

Monthly frequency is used because we are interested mainly in long-term fundamental factors between the two variables. Given the much higher efficiency of the foreign exchange market compared to the oil market, the average volatility of the dollar was more than five times lower than that of the Brent oil price in the period under review (see Figure 2). Moreover, the oil market is characterised by low price elasticity of demand and supply. Therefore, greater price fluctuations are necessary to achieve equilibrium on the oil market. Oil supply is affected above all by limited reserve capacity, which is concentrated largely in just one country (Saudi Arabia) and by the long time - often between five and ten years - it takes to establish new oil fields for commercial use.

Figure 1

Evolution of the Brent Crude Oil Price and the US Dollar

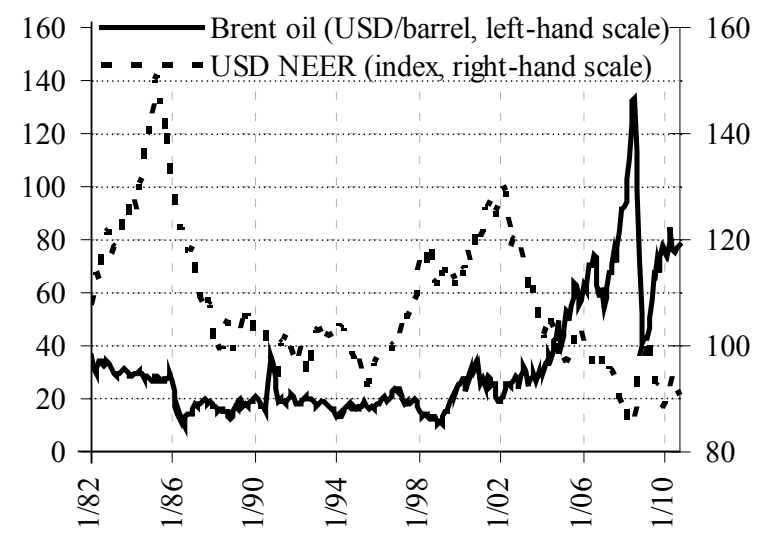

2 The source of the data on the nominal effective exchange rate (NEER) of the US dollar is the database of the International Monetary Fund (IMF-IFS). The correlation between month-on-month changes in NEER and the EUR/USD bilateral exchange rate was 0.9 in that period (synthetic euro used before 1999). 
Figure 2

Historical Volatility of Monthly Returns

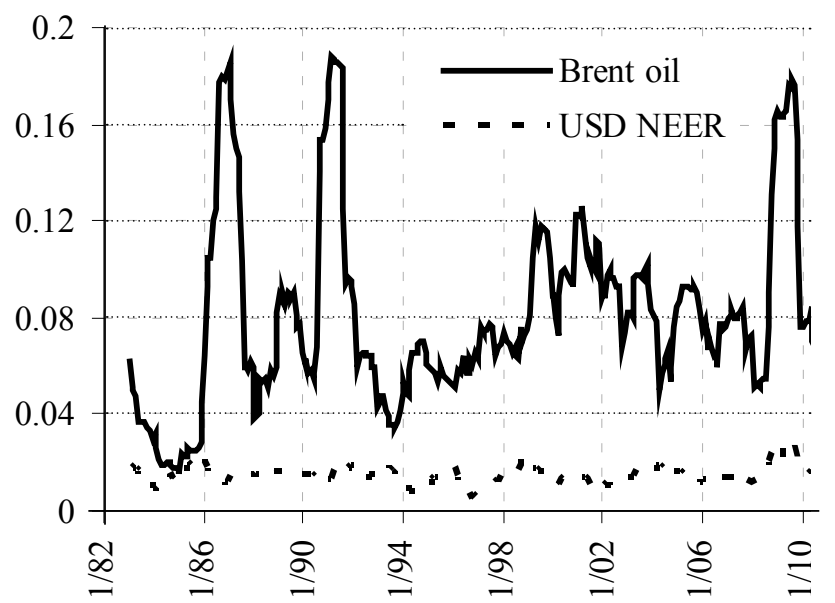

Note: Monthly averages between January 1982 and September 2010 (345 observations).

Brent oil price (USD/barrel) - minimum/average/maximum: 9.5/32.2/133.6

USD NEER - minimum/average/maximum: 85.5/108.1/151.1

An increase in the USD NEER index represents appreciation of the US dollar. Historical volatility (Figure 2 ) is calculated as the annual moving standard deviation of the logarithmic monthly returns.

Source: Thomson Reuters (Datastream) and International Monetary Fund (IMF-IFS)

Figure 2 also shows that the recent increase in oil market volatility accompanied by sharp growth in oil prices was by no means unusual from the historical perspective. However, the most recent upswing in oil price volatility was also accompanied by increased foreign exchange market volatility; this contrasted with the previous two episodes of increased volatility in 1986 and 1990, which were linked in the first case with a marked drop in oil demand and with excess oil production (a sharp fall in the price of oil) and in the second case with Iraq's invasion of Kuwait, which, on the contrary, was connected with a steep rise in the price of oil. From this we can also indirectly infer an increase in the intensity of the relationship between the two variables.

As both time series - the Brent oil price as well as the nominal effective exchange rate of the dollar - are non-stationary, we examine the interdependence between their monthly logarithmic returns, which fulfil the condition of stationarity. The monthly logarithmic returns are expressed by the equation:

$$
v_{\log }=\ln \left(\frac{p_{t}}{p_{t-1}}\right)
$$

where $p$ is the average monthly value of the variable at time $t$ or $t-1$. 
This approach differs from that of previous authors, who examined the interdependence between the absolute values of these variables. According to Deutsche Bank Research (2009) and Hošek et al. (2011), the coefficient of correlation between the two variables in the period 2000-2009 was relatively high (-0.9). Similarly, Cuaresma and Breitenfellner (2008) report high coefficients of correlation between the price of oil and the USD/EUR exchange rate in 1998-2006 (-0.73).

The evolution of the calculated annual moving coefficient of correlation between monthly returns on the price of Brent oil and the nominal effective exchange rate of the US dollar, as well as the correlation coefficients for the three selected periods (below the figure) are shown in Figure 3. For comparison, corresponding correlation coefficients were also calculated between the dollar exchange rate and agricultural commodity prices (S\&P GSCI Agricultural), the price of gold and prices of industrial metals (S\&P GSCI Industrial Metals) (see Figures 4-6).

In line with the previous literature, the rolling correlation coefficients were in most cases negative (depreciation of the dollar was associated with higher commodity prices and appreciation with lower prices), while the intensity of the correlation has recently increased for oil as well as for industrial metals and agricultural commodities. The intensity of the inverse relationship declined only for gold in 2009/10. Despite that, gold has long been characterised by a relatively high negative correlation with the exchange rate of the dollar. From a historical perspective, gold has therefore traditionally been a safe alternative investment to dollar financial assets.

A very similar inverse relationship between monthly returns on gold holdings and the nominal effective exchange rate of the dollar is also obtained on the basis of a statespace model by Frait and Komárek (2006), who state that an inverse relationship arises in periods when the dollar is not stable and investors try to find a more durable asset, hence gold (along with other precious metals) becomes more attractive.

In addition to industrial metals, which have been showing a gradually increasing inverse relationship with the dollar exchange rate for a long time, Brent crude oil and agricultural commodities have recorded sharp growth in their inverse correlation in recent years. This correlation is more pronounced for Brent oil. In line with our assumptions, it therefore really does seem that investors probably seek alternative investment returns on commodity markets in an environment of low real interest rates and excess liquidity. 
Figures 3-6

Annual Moving Coefficient of Correlation between Monthly Returns on the Nominal Effective Exchange Rate of the US Dollar and Selected Commodities
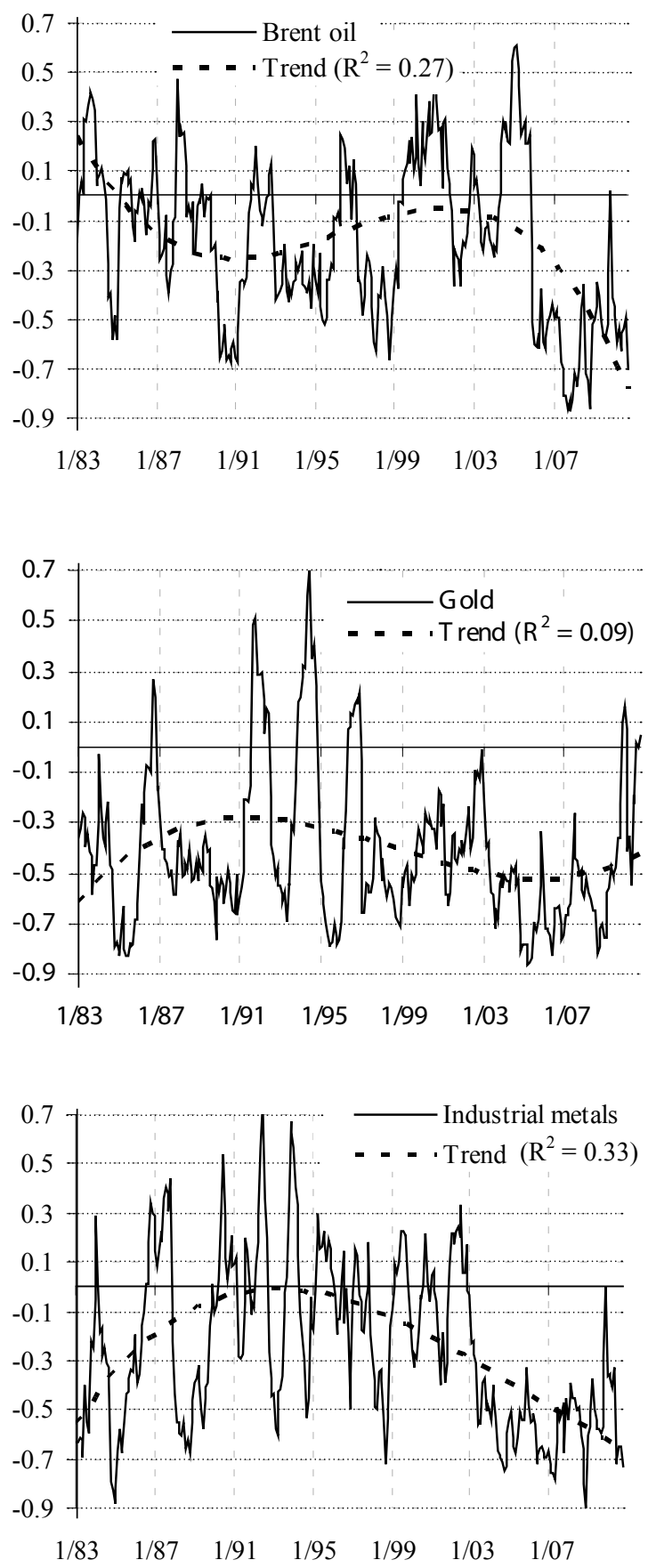

Correlation coefficient 1982:1-2010:9 = -0.2 Correlation coefficient 2002:1-2010:9 $=-0.36$ Correlation coefficient 2007:1-2010:9 $=-0.58$ Granger causality: USD $\rightarrow$ Brent (since 2002)
Correlation coefficient 1982:1-2010:9 $=-0.4$ Correlation coefficient 2002:1-2010:9 $=-0.47$ Correlation coefficient 2007:1-2010:9 $=-0.44$ Granger causality: impossible to determine definitely
Correlation coefficient 1982:1-2010:9 $=-0.36$ Correlation coefficient 2002:1-2010:9 $=-0.53$ Correlation coefficient 2007:1-2010:9 = -0.6 Granger causality: impossible to determine definitely 


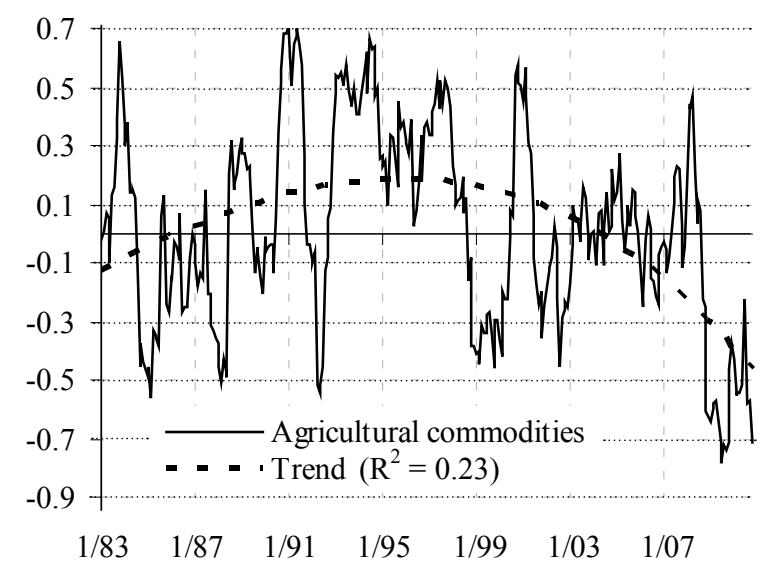

Correlation coefficient 1982:1-2010:9 $=-0.13$ Correlation coefficient 2002:1-2010:9 $=-0.33$ Correlation coefficient 2007:1-2010:9 = -0.53 Granger causality: impossible to determine definitely

Note: Correlation coefficients for the three selected periods are shown under the figures. Granger causality was confirmed only for Brent oil (from the exchange rate to the Brent oil price). The trend is expressed by a third-degree polynomial. The corresponding coefficients of determination are shown in brackets.

Source: Thomson Reuters (Datastream), International Monetary Fund (IMF-IFS), monthly data, authors' calculations.

Specifically, three-month rates on the US dollar money market have averaged only $2.0 \%$ since 2002 compared to $6.0 \%$ in $1982-2001$. In real terms, interest rates were $2.6 \%$ in 1982-2001 and have declined to an average of $-0.4 \%$ since 2002 . Above and beyond traditional fundamental factors, additional speculative demand has therefore probably been driving up commodity prices in recent years.

\section{Factors Affecting the Price of Oil}

Based on the above findings, in the next step, we quantify potential factors affecting the price of Brent oil, including the nominal effective exchange rate of the dollar.

In contrast to Cuaresma and Breitenfellner (2008) or Lizardo and Mollick (2010) who, in general, add oil prices to the basic monetary model of exchange rate determination ${ }^{3}$, we directly estimate an equation of the Brent oil price that contains other relevant variables in addition to the nominal effective exchange rate on the right-hand side of the equation. This specification is supported by the Granger causality which goes from the exchange rate to the Brent oil price (see Figure 3). Moreover, the same causality is also found in Zhang et al. (2008). In formal we write:

3 Cuaresma and Breitenfellner (2008) assess the predictive power of the USD/EUR nominal exchange rate for estimating future oil prices using a VAR/VEC model incorporating the USD/EUR exchange rate, its determinants (the relative money supply, relative output and relative interest rates between the USA and the euro area) and the price of oil. Lizardo and Mollick (2010) use nominal exchange rate of the U.S. dollar, real oil prices (WTI), relative money supply and relative industrial production between the USA and other countries (both oil exporters and oil importers) in their model. 


$$
\begin{aligned}
\Delta \ln \left(\text { Brent }_{t}\right) & =\beta_{1} \Delta \ln \left(N E E R_{t}^{U S D}\right)+\beta_{2} \Delta \ln \left(I P_{t}^{\text {OECD }}\right)+\beta_{3} \Delta r_{t}^{U S D}+\beta_{4} \Delta \ln \left(\text { OIL_INV } V_{t-1}^{U S A}\right) \\
& +\beta_{5} \Delta R E F I N E R Y_{t-2}^{U S A}+\varepsilon_{t}
\end{aligned}
$$

where Brent $_{t}$ is the nominal price of Brent crude oil in US dollars per barrel; $N E E R_{t}^{U S D}$ is the nominal effective exchange rate of the dollar (growth in the index implies appreciation of the dollar); $I P_{t}^{O E C D}$ is the seasonally adjusted industrial production index in OECD countries; $r_{t}^{U S D}$ denotes three-month real interest rates in the USA; $O I L \_I N V_{t-1}^{U S A}$ are oil inventories in the USA excluding strategic reserves in barrels, adjusted for seasonal effects; $R E F I N E R Y_{t-2}^{U S A}$ is the percentage rate of use of oil refineries in the USA, adjusted for seasonal effects; and $t$ is time in months. The corresponding coefficients are expressed by $\beta_{1}$ through $\beta_{5}$, while $\varepsilon_{\mathrm{t}}$ is the i.i.d. term. ${ }^{4}$

Table 1

Summary Statistics for Variables in Equation 2 (1994:1-2010:9)

\begin{tabular}{|l|l|l|l|l|l|l|}
\hline & Brent & NEER & IPOECD & rUSD & $\begin{array}{c}\text { OIL_INVUSA } \\
\text { (thousand barrels) }\end{array}$ & REFINERYUSA \\
\hline Mean & 39.4 & 104.9 & 92.9 & 0.9 & 315.7 & 91.1 \\
\hline Median & 27.9 & 101.9 & 93.7 & 1.2 & 314.4 & 92.1 \\
\hline Maximum & 133.6 & 130.2 & 109.2 & 3.7 & 366.7 & 100.2 \\
\hline Minimum & 10.2 & 85.5 & 73.4 & -3.9 & 271.2 & 74.8 \\
\hline Std. Dev. & 26.6 & 11.1 & 9.0 & 1.8 & 21.0 & 4.1 \\
\hline Skewness & 1.21 & 0.43 & -0.23 & -0.52 & -0.04 & -1.12 \\
\hline Kurtosis & 3.93 & 2.25 & 2.32 & 2.22 & 2.24 & 4.38 \\
\hline
\end{tabular}

Table 1 shows main descriptive statistics of the variables used in the Equation 2. Full and consistent data for all variables was found from 1994 onward. We picked the variables which we believe are highly relevant for the evolution of the Brent crude oil price. Industrial production in OECD countries represents the global demand for oil stemming from the total world economic activity. We also tried to incorporate industrial production in China and India in the equation, as these countries have been characterized by huge increases in oil consumption in recent years. However, neither variable was statistically significant. Demand from China and India is probably a recent phenomenon which is not entirely reflected in our data. The low quality of data for these countries may also play a role.

The next variable which we believe helps us in determination of oil prices is the shortterm real interest rate in the USA. As it was already discussed in the text, we believe that commodities including the crude oil represent alternatives to financial assets.

4 The data are taken from the databases of IMF-IFS (NEER $\left.{ }_{t}^{U S D}\right)$, Thomson Reuters $\left(\right.$ Brent $\left._{t}, r_{t}^{U S D}\right)$, Bloomberg $\left(O I L_{-} I N V_{t-1}^{U S A}, R E F I N E R Y_{t-2}^{U S A}\right)$ and $\operatorname{OECD}\left(I P_{t}^{O E C D}\right)$. 
Therefore, if the global liquidity is ample and returns from traditional financial assets are going down, investors are seeking new investment opportunities on commodity markets.

If we skip the nominal exchange rate of the US dollar which is according to our preliminary analysis closely related to the oil price and possible reasons for that have been already discussed, the two remaining variables demonstrate the situation on the US oil market. Specifically, as the USA is the world biggest oil consumer, we incorporated in our equation oil inventories in the USA excluding strategic reserves and the percentage rate of use of oil refineries in the USA. Both variables depict tightness on the US oil market.

We have initially considered a variable expressing the OPEC oil supply as well. However, this variable has not proved to be statistically significant.

\subsection{Results of the Estimate}

The Equation 2 was estimated using monthly data from January 1994 to September 2010. Within this period, we identified a structural break in December 2004 using the Chow test. For this reason the results are presented separately for two periods: up to December 2004 and from January 2005 onwards.

Table 2

Estimate of Variables Affecting the Price of Brent Crude Oil (Equation 2)

\begin{tabular}{|c|c|c|}
\hline & 1994:1-2004:12 & 2005:1-2010:9 \\
\hline$\Delta \ln \left(N E E R_{t}^{U S D}\right)$ & $-0.025(0.453)$ & $-2.125^{\star * *}(0.545)$ \\
\hline$\Delta \ln \left(I P_{t}^{O E C D}\right)$ & $5.308^{* \star *}(1.385)$ & $3.263^{\star * *}(0.979)$ \\
\hline$\Delta r_{t}^{U S D}$ & $-0.074^{* * *}(0.021)$ & $-0.036^{* *}(0.015)$ \\
\hline$\Delta \ln \left(O I L_{-} I N V_{t-1}^{U S A}\right)$ & $0.74^{* *}(0.283)$ & $0.356(0.406)$ \\
\hline$\Delta R E F I N E R Y_{t-2}^{U S A}$ & $0.008^{* \star *}(0.003)$ & $0.004(0.003)$ \\
\hline $\bar{R}^{2}$ & 0.18 & 0.45 \\
\hline$D-W$ & 1.94 & 1.71 \\
\hline Number of observations & 132 & 69 \\
\hline $\begin{array}{l}\text { Dependent variable (avg./ } \\
\text { std. dev.) }\end{array}$ & $0.008 / 0.084$ & $0.01 / 0.099$ \\
\hline
\end{tabular}

Note: Estimated by the least squares method. Standard errors of the coefficient estimates are shown in brackets. Asterisks denote significance as follows: ${ }^{* *} 1 \%$, ${ }^{*} 5 \%$. 
Until 2005 the effect of the dollar exchange rate on the Brent oil price is statistically insignificant with a very low coefficient. All the other explanatory variables are statistically significant, with industrial production in OECD countries having the largest effect. Growth in industrial production of $1 \%$ had an upward effect on the oil price of around $5.3 \%$. This relationship confirms the inelasticity of demand for oil, with a small increase in demand for oil causing a several times higher increase in the oil price. ${ }^{5}$ Growth in real interest rates causes the oil price to decline, confirming our hypothesis that investors seek investment returns on commodity markets if the return on financial assets is low. The remaining two variables capture the effects of oil inventories and the rate of use of refineries in the USA. Growth in oil inventories with a one-month lag pushes the price of oil upwards which is probably connected with higher demand for oil in order to rebuilt existing inventories. Similarly, growth in the use of refineries with a two-month lag results in an increase in the price of oil because refineries demand more oil for their operation. The said model specification explains about one-fifth of the total oil price variability until 2005.

The model's explanatory power increased significantly from 2005 onwards (to about one-half). However, the nominal effective exchange rate of the dollar also ranked among the statistically significant variables. An appreciation of the dollar of $1 \%$ represents a fall in the Brent oil price of $2.1 \%$. For comparison, Brown et al. (2008) estimate that the weakening of the dollar against the euro between 2003 and 2007 accounted for one-third of the oil price growth in the same period. This would mean that a depreciation of the dollar of $1 \%$ caused an increase in the oil price of around $2.4 \%$. Furthermore, Zhang et al. (2008) estimate the long-term elasticity coefficient of oil price over the USD/EUR exchange rate to 1.3. If we used the bilateral EUR/USD rate directly in the equation instead of the effective exchange rate of the dollar, we would get the same coefficient (-1.3).

The structural break in 2004 has been probably connected with world broad money which was growing at its fastest rate since the late 1980s in 2004 and 2005 (Rueffer and Stracca, 2006) and with lower prospects of the US dollar (lack of investment opportunities in the USA and cash hoarding by nonfinancial companies). As a result, large amounts of money have been shifted to commodity markets and the oil market in particular. Weakening of the US dollar thus became the main driving factor leading the price of oil to rise.

Together with the dollar, industrial production in OECD countries remains another statistically significant variable affecting the oil price. Growth in this variable causes an increase in the oil price. The dollar exchange rate and industrial production therefore have contrary effects on the oil price.

As regards the remaining variables, only short-term real interest rates in the USA maintained a statistically significant effect, albeit with a lower coefficient. As in the period up to 2005, their growth causes the oil price to fall.

5 According to most estimates, a movement in the oil price of $10 \%$ requires a movement in demand for oil of only slightly more than $0.02 \%$. 


\subsection{Implications for the Czech Economy}

The observed inverse relationship between the Brent crude oil price and the US dollar exchange rate dampens the impact of sharp fluctuations in the dollar price of Brent oil in "non-dollar" economies including the Czech Republic.

Figure 7

Evolution of the Brent Crude Oil Price in USD, EUR and CZK (January 1994=100)

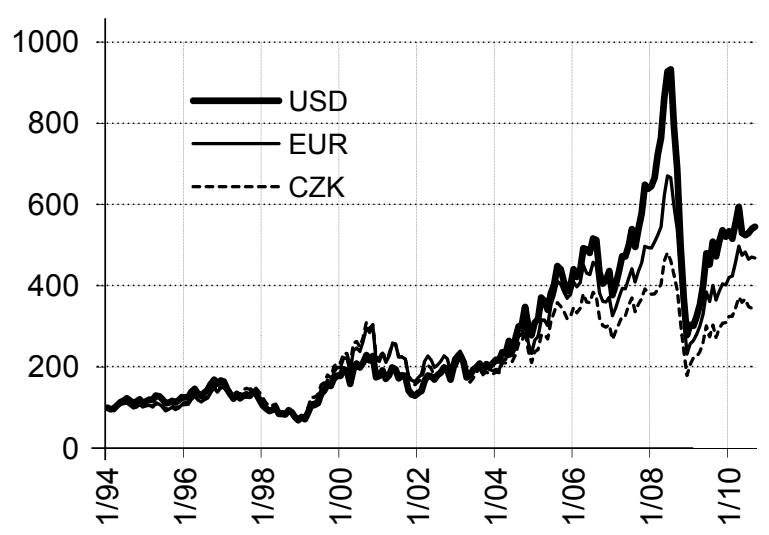

Source: Thomson Reuters (Datastream)

According to Babetskaia-Kukharchuk et al. (2008), the dynamic correlation coefficient between the koruna-dollar and euro-dollar currency pairs was 0.9 for the Czech Republic. The Czech koruna is therefore characterised by a high tendency to move similarly against the US dollar as the euro. ${ }^{6}$ The impacts of fluctuations in dollar prices of oil on the Czech economy are therefore dampened similarly as in the euro area countries. Moreover, the dampening effect on the Czech Republic is increased by long-term nominal appreciation of the koruna against the euro, as the average annual appreciation of the koruna against the euro has been $3.1 \%$ since 2002 .

Figure 7 demonstrates that volatility of the Brent crude oil price denominated in the Czech currency (CZK) was lower than that denominated in the euro currency and certainly than that denominated in US dollars.

The Czech economy thus benefited from the contrary movement between the US dollar exchange rate and the oil price. Growth in the dollar price of oil was dampened mainly between August 2007 and September 2008, when the difference in annual growth between the dollar and koruna price of Brent oil was 20 percentage points (as against 11 percentage points relative to the euro price of oil).

6 Updated correlation coefficients (CNB, 2010, p. 42) confirm a high dependence in 2010 as well. The correlation decreased only in 2008 H2 and in 2009 Q1, when the koruna was exposed to depreciation pressures linked with increased volatility in global financial markets. 


\section{Conclusions}

We demonstrate that in recent years the correlation coefficients were negative between the US dollar exchange rate and commodity prices (depreciation of the dollar was associated with higher commodity prices and appreciation with lower prices). The intensity of the correlation has recently increased for oil as well as for industrial metals and agricultural commodities. We thus infer that above and beyond traditional fundamental factors, additional speculative demand caused by low interest rates and excess liquidity in developed countries has therefore probably been driving up commodity prices in recent years. Large amounts of money have been shifted to commodity markets.

In contrast to previous literature which, in general, adds oil prices to the basic monetary model of exchange rate determination, we directly estimate an equation of the Brent oil price that contains other relevant variables in addition to the nominal effective exchange rate of the US dollar in the period from 1994 to 2010.

We find that since 2005 a depreciation of the nominal effective exchange rate of the dollar of $1 \%$ has implied an increase in the oil price of $2.1 \%$. Together with the US dollar industrial production in OECD countries and short-term real interest rates in the USA were statistically significant determinants of the Brent crude oil price. Growth in industrial production causes an increase in the oil price while interest rates growth causes the oil price to fall.

Consequently, the inverse relationship between the Brent crude oil price and the US dollar exchange rate dampens the impact of sharp fluctuations in the dollar price of Brent oil in "non-dollar" economies. The exchange rate thus absorbs the impact of high volatility in dollar prices of oil on both the euro area countries and other economies linked to the euro area, including the Czech Republic.

Growth in the dollar price of oil was dampened mainly between August 2007 and September 2008, when the difference in annual growth between the dollar and koruna price of Brent oil was 20 percentage points (as against 11 percentage points relative to the euro price of oil).

\section{References}

Amano, R. A., van Norden, S. (1998a), "Exchange Rates and Oil Prices." Review of International Economics, Vol. 6, No. 4, pp. 683-694.

Amano, R. A., van Norden, S. (1998b), "Oil Prices and the Rise and Fall of the US Real Exchange Rate." Journal of International Money and Finance, Vol. 17, pp. 299-316.

Babetskaia-Kukharchuk, O., Babetskii, I., Podpiera, J. (2008), "Convergence in Exchange Rates: Market's View on CE-4 Joining EMU." Applied Economic Letters, Vol. 15, pp. 385-390.

Bénassy-Quéré, A., Mignon, V., Penot, A. (2005), "China and the Relationship between the Oil Price and the Dollar." CEPII Working Paper No. 2005-16.

Brown, S. P. A., Virmani, R., Alm, R. (2008), "Crude Awakening: Behind the Surge in Oil Prices." Economic Letter - Federal Reserve Bank of Dallas, Vol. 5, No. 3. 
Chaudhuri, K., Daniel, B.C. (1998), "Long-Run Equilibrium Real Exchange Rates and Oil Prices." Economics Letters, Vol. 58, pp. 231-238.

Cuaresma, J. C., Breitenfellner, A. (2008), "Crude Oil Prices and the Euro-Dollar Exchange Rate: A Forecasting Exercise." University of Innsbruck - Working Papers in Economics and Statistics No. 08.

Czech National Bank (2010), Analyses of the Czech Republic's Current Economic Alignment with the Euro Area. Prague: Czech National Bank. Dostupné na http://www.cnb.cz/miranda2/ export/sites/www.cnb.cz/en/monetary_policy/strategic_documents/download/analyses_of_ alignment_2010.pdf

Deutsche Bank Research (2009), Exchange Rate Perspectives - Of Growth \& Gaps: The Oil \& Dollar Cycle Revisited. DB Global Markets Research.

European Commission (2008), First Interim Report on Oil Price Developments and Measures to Mitigate the Impact of Increased Oil Prices. ECFIN/REP 54538-EN.

Frait, J., Komárek, L. (2006), "Půl století vývoje světových peněz (Half a Century of Global Money Developments)." Politická ekonomie, Vol. 54, No. 3, pp. 307-325.

Habib, M. M., Kalamova, M. (2007), "Are There Oil Currencies? The Real Exchange Rate of Oil Exporting Countries." Working Paper Series No. 839, European Central Bank.

Hošek, J., Komárek, L., Motl, M. (2011), “Měnová politika a cena ropy (Monetary Policy and the Price of Oil)." Politická ekonomie, Vol. 59, No. 1, pp. 22-46.

Lizardo, R. A., Mollick, A. V. (2010), "Oil price fluctuations and U.S. dollar exchange rates." Energy Economics, Vol. 32, pp. 399-408.

Mileva, E., Siegfried, N. (2007), "Oil Market Structure, Network Effects and the Choice of Currency for Oil Invoicing." Occasional Paper Series No. 77, European Central Bank.

Muñoz, M. P., Dickey, D. A. (2009), "Are Electricity Prices Affected by the US Dollar to Euro Exchange Rate? The Spanish Case." Energy Economics, Vol. 31, No. 6, pp. 857-866.

Rueffer, R., Stracca, L. (2006), "What is Global Excess Liquidity, and Does It Matter?" Working Paper Series No. 696, European Central Bank.

Schulmeister, S. (2009), "Trading Practices and Price Dynamics in Commodity Markets and the Stabilizing Effects of a Transaction Tax." WIFO (Austrian Institute of Economic Research).

Zhang, Y., Fan, Y., Tsai, H., Wei, Y. (2008), "Spillover Effect of US Dollar Exchange Rate on Oil Prices." Journal of Policy Modeling, Vol. 30, No. 6, pp. 973-991. 